\title{
MARKET-WEIGHTED TRENDS IN THE DESIGN ATTRIBUTES OF HEADLAMPS IN THE U.S.
}

\section{BRANDON SCHOETTLE MICHAEL SIVAK NAOKO TAKENOBU}

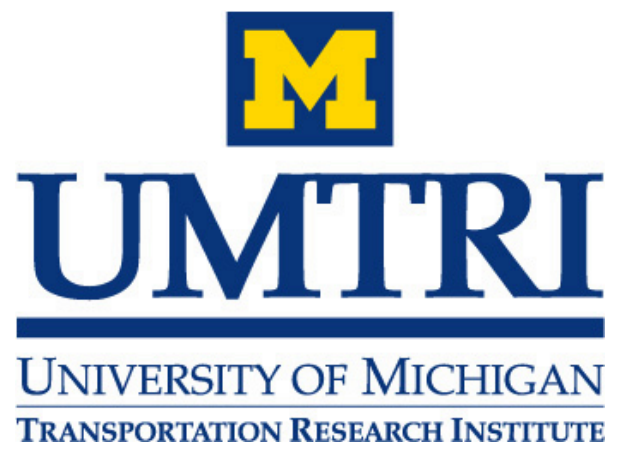




\title{
MARKET-WEIGHTED TRENDS IN THE DESIGN ATTRIBUTES OF HEADLAMPS IN THE U.S.
}

\author{
Brandon Schoettle \\ Michael Sivak \\ Naoko Takenobu
}

The University of Michigan

Transportation Research Institute

Ann Arbor, Michigan 48109-2150

U.S.A.

Report No. UMTRI-2007-20

June 2007 


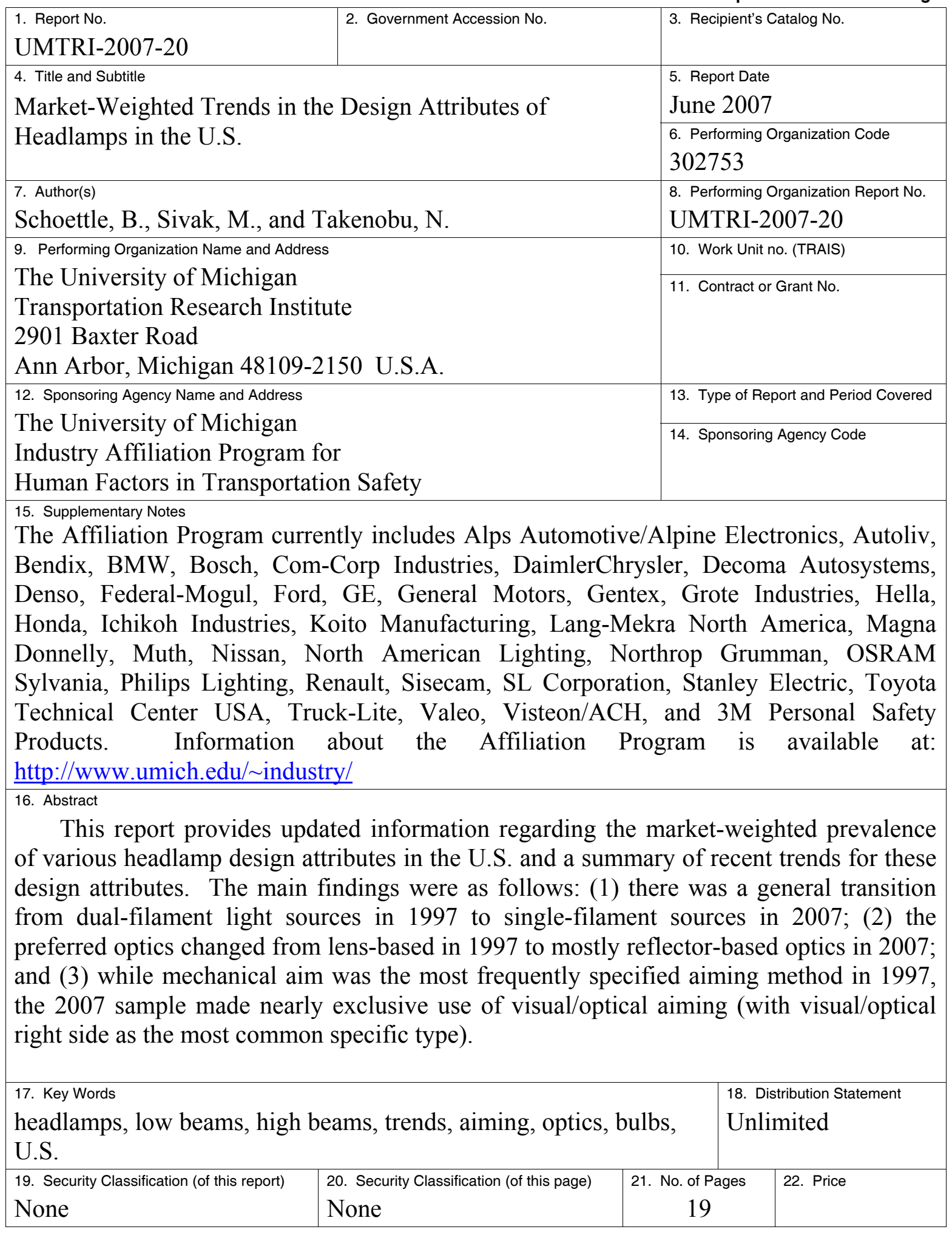




\section{Acknowledgments}

Appreciation is extended to the members of the University of Michigan Industry Affiliation Program for Human Factors in Transportation Safety for support of this research. The current members of the Program are:

\begin{tabular}{ll} 
Alps Automotive/Alpine Electronics & Koito Manufacturing \\
Autoliv & Lang-Mekra North America \\
Bendix & Magna Donnelly \\
BMW & Muth \\
Bosch & Nissan \\
Com-Corp Industries & North American Lighting \\
DaimlerChrysler & Northrop Grumman \\
Decoma Autosystems & OSRAM Sylvania \\
Denso & Philips Lighting \\
Federal-Mogul & Renault \\
Ford & Sisecam \\
GE & SL Corporation \\
General Motors & Stanley Electric \\
Gentex & Toyota Technical Center, USA \\
Grote Industries & Truck-Lite \\
Hella & Valeo \\
Honda & Visteon/ACH \\
Ichikoh Industries & 3 M Personal Safety Products \\
\hline
\end{tabular}




\section{Contents}

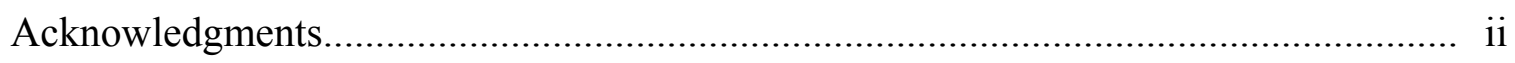

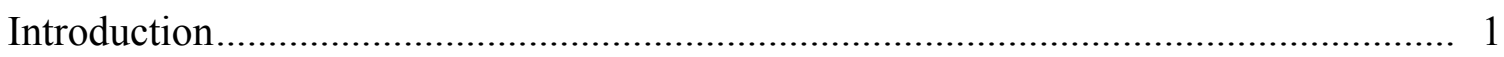

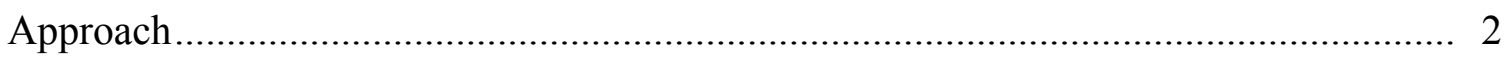

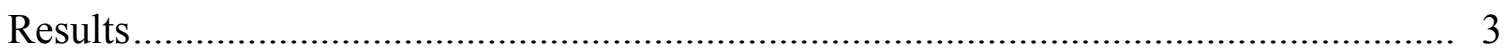

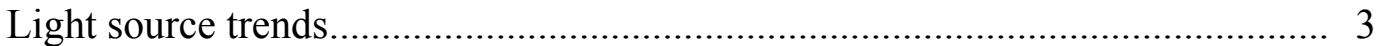

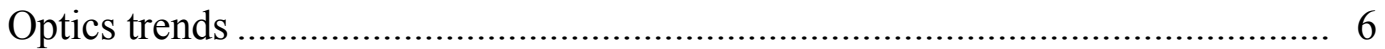

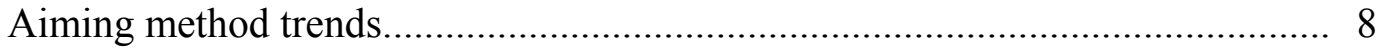

Lens material trends............................................................................ 9

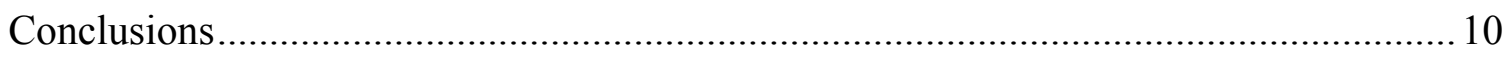

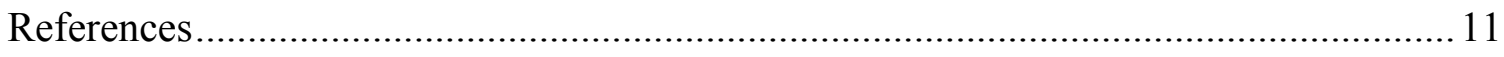

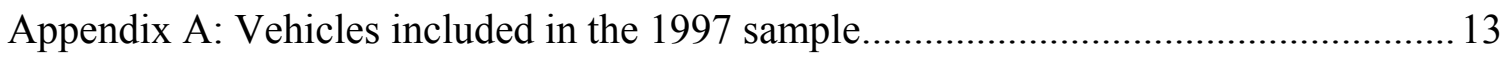

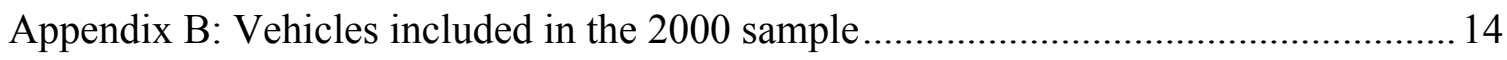

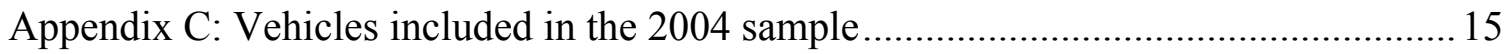

Appendix D: Vehicles included in the 2007 sample................................................... 16 


\section{Introduction}

Driven by improvements in automotive lighting technology and regulatory changes over several recent decades, headlamp designers now enjoy a considerable range of flexibility in determining the ultimate design and implementation of headlamps for new vehicle models. The attributes accounting for the majority of this increased flexibility include the light source, optics, and aiming method specified for each headlamp. Over the past decade, significant changes to these attributes, and thus the design choices exercised by lighting designers and vehicle manufacturers, have occurred for headlamps on vehicles sold in the U.S.

Starting with the 1997 model year, we have periodically documented the various technical and photometric attributes of headlamps in the U.S. for the top-selling vehicles (Sivak, Flannagan, Kojima, \& Traube, 1997; Schoettle, Sivak, \& Flannagan, 2001; Schoettle, Sivak, Flannagan, \& Kosmatka, 2004). To update this cumulative database of headlamp attributes, a new survey was conducted to document the state of headlamps in the U.S. for the 2007 model year.

This report provides updated information regarding the market-weighted prevalence of various headlamp attributes in the U.S. and a summary of recent trends in the U.S. for these attributes. 


\section{Approach}

\section{Samples}

Table 1 describes the four samples used in these analyses. The information that was collected was market-weighted by the respective sales figures for each individual vehicle (Automotive News, 2001, 2004, 2007; Ward's Automotive Reports, 1997).

Table 1

Summary of the lamp samples used in these analyses.

\begin{tabular}{|l|c|c|l|}
\hline Model year & $\begin{array}{c}\text { Number of } \\
\text { unique lamps }\end{array}$ & $\begin{array}{c}\text { Market-weighted } \\
\text { percentage of all } \\
\text { vehicles sold }\end{array}$ & \multicolumn{1}{|c|}{ Study } \\
\hline \hline 1997 & 23 & 45.2 & Sivak et al. (1997) \\
\hline 2000 & 20 & 39.3 & Schoettle et al. (2001) \\
\hline 2004 & 20 & 38.8 & Schoettle et al. (2004) \\
\hline 2007 & 50 & 58.6 & present study \\
\hline
\end{tabular}

All lamps in these analyses were either directly purchased from vehicle dealerships in Ann Arbor, Michigan (1997, 2000, and 2004 samples), or inspected while on the lot at the same local dealerships (2007 sample). When more than one headlamp option was offered for a vehicle, the base-model lamp was documented. For a complete listing of vehicles included in each sample, see Appendices A through D.

\section{Lamp surveys}

A visual and physical inspection was made of each headlamp. The following information was documented:

- Light source (low and high beam)

- Optics (low and high beam)

- Aiming method

- Lens material 


\section{Results}

\section{Light source trends}

The light sources for the sampled low beams are summarized in Table 2. The corresponding information for high beams is shown in Table 3. The information in these tables is analogously presented in graphical form in Figures 1 and 2.

The main trend for the low-beam sample involves a transition from HB5 (44\% in $1997,15 \%$ in 2007$)$ to $\mathrm{H} 11$ ( $0 \%$ in $1997,32 \%$ in 2007). HB4 remains the second most common light source for all years except 2004 (when it was the most common light source). Over this period, the usage of HB2 has decreased substantially (from $12 \%$ in 1997 to $4 \%$ in 2007), and HB1 was no longer present in the two most recent samples.

The main trend for the high-beam sample involves a transition from HB5 (44\% in $1997,15 \%$ in 2007 ) to HB3 (34\% in $1997,47 \%$ in 2007). The newer H13 is the second most common light source for the current model year. As with the low-beam samples, usage of HB2 has decreased substantially, and HB1 was no longer present in the two most recent samples.

These shifts from the dual-filament HB5 in both the low- and high-beam samples to the single-filament H11 (low beam) and HB3 (high beam) also indicate a gradual shift from two-lamp systems to four-lamp systems. (For an analysis of the relative merits of two- and four-lamp systems, see Rumar [2000].)

While several bulbs have decreased in usage (or disappeared from our samples altogether), there is a clear trend toward an increased diversity of light sources. Both low- and high-beam samples employed only four bulb types in the 1997 and 2000 samples, increasing to seven (low beam) and eight (high beam) for the current model year. This trend is not an effect of the increased sample size for the 2007 model year, as all of the light sources documented in this report are present in both the 20 best-selling vehicles (a sample size similar to the previous studies), as well as the 50 best-selling vehicles that were included in this analysis. This increased diversity is a result of more frequent usage of newer tungsten-halogen bulb technology (H9, H11, and H13) and the recent appearance of HID (D4R) as standard equipment on a top-selling vehicle. 
Table 2

Light sources used in the sampled low-beam headlamps. The entries in each cell are sales-weighted percentages. The most frequently installed equipment for each year is shown in bold. (H11, H13, and D4R became legal equipment in 1999, 2002, and 2005, respectively [NHTSA, 1999b, 2002, 2005].)

\begin{tabular}{|l|c|r|r|r|r|}
\hline \multicolumn{2}{|c|}{ Light sources } & \multicolumn{4}{c|}{ Model year } \\
\hline Designation & $\begin{array}{c}\text { Number of } \\
\text { filaments }\end{array}$ & 1997 & 2000 & 2004 & 2007 \\
\hline HB1 (9004) & 2 & 9.3 & 5.6 & & \\
\hline HB2 (9003) & 2 & 12.5 & 12.3 & 3.6 & 3.6 \\
\hline HB4 (9006) & 1 & 34.3 & 35.0 & $\mathbf{5 7 . 8}$ & 27.1 \\
\hline HB5 (9007) & 2 & $\mathbf{4 3 . 9}$ & $\mathbf{4 7 . 1}$ & 22.4 & 14.8 \\
\hline H1 & 1 & & & 3.1 & \\
\hline H7 & 1 & & & & 3.8 \\
\hline H11 & 1 & & & & $\mathbf{3 1 . 8}$ \\
\hline H13 & 2 & & & 13.1 & 17.8 \\
\hline D4R & n/a & & & & 1.1 \\
\hline
\end{tabular}

Table 3

Light sources used in the sampled high-beam headlamps. The entries in each cell are sales-weighted percentages. The most frequently installed equipment for each year is shown in bold. (H9, H13, and D4R became legal equipment in 1999, 2002, and 2005, respectively [NHTSA, 1999a, 2002, 2005].)

\begin{tabular}{|l|c|r|r|r|r|}
\hline \multicolumn{2}{|c|}{ Light sources } & \multicolumn{4}{c|}{ Model year } \\
\hline Designation & $\begin{array}{c}\text { Number of } \\
\text { filaments }\end{array}$ & 1997 & 2000 & 2004 & 2007 \\
\hline HB1 (9004) & 2 & 9.3 & 5.6 & & \\
\hline HB2 (9003) & 2 & 12.5 & 12.3 & 3.6 & 3.6 \\
\hline HB3 (9005) & 1 & 34.3 & 35.0 & $\mathbf{6 0 . 9}$ & $\mathbf{4 7 . 1}$ \\
\hline HB5 (9007) & 2 & $\mathbf{4 3 . 9}$ & $\mathbf{4 7 . 1}$ & 22.4 & 14.8 \\
\hline H1 & 1 & & & & 1.5 \\
\hline H7 & 1 & & & & 5.4 \\
\hline H9 & 1 & & & & 8.7 \\
\hline H13 & 2 & & & 13.1 & 17.8 \\
\hline D4R & n/a & & & & 1.1 \\
\hline
\end{tabular}




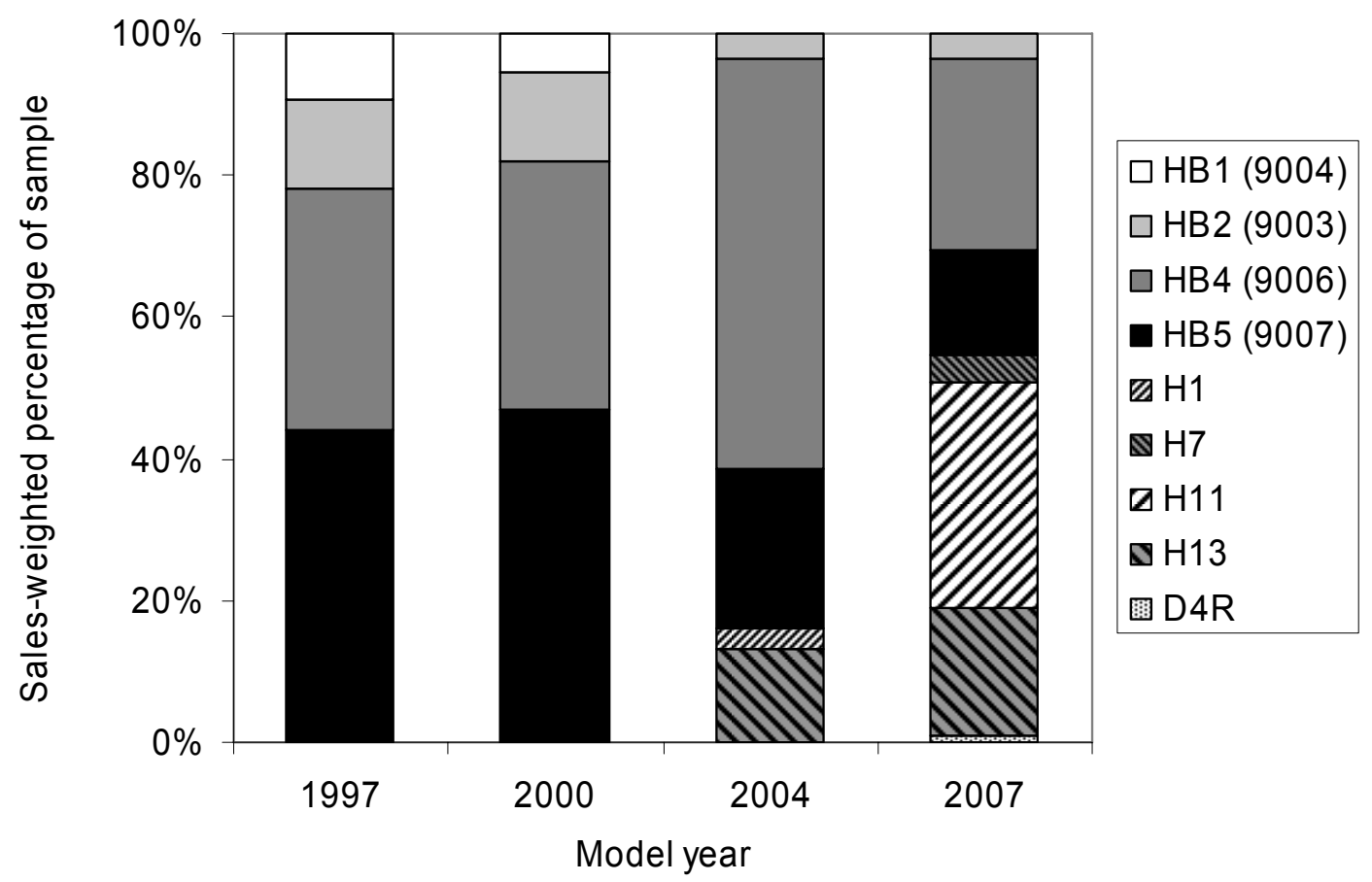

Figure 1. Sales-weighted distribution of low-beam light sources within each sample.

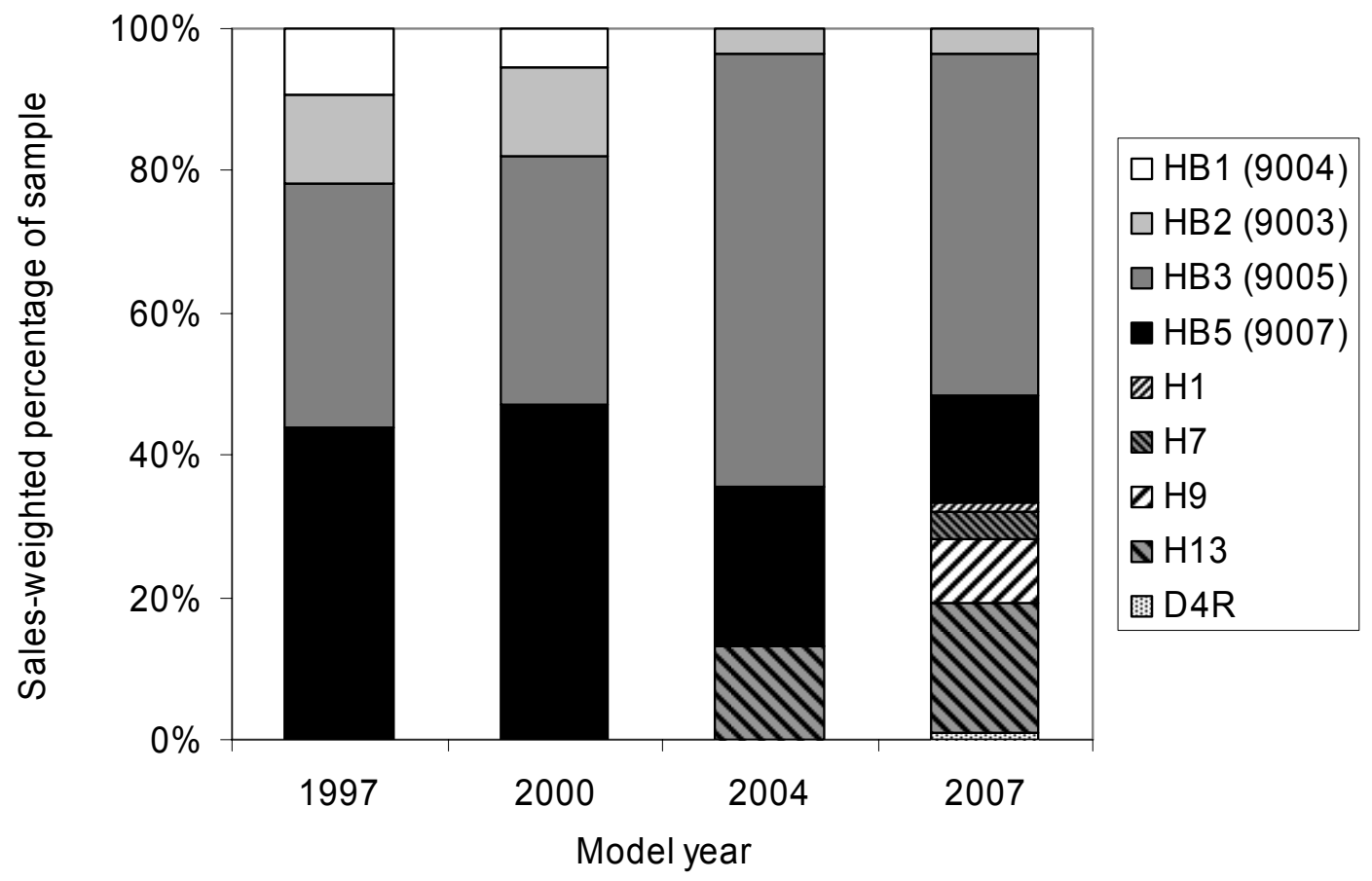

Figure 2. Sales-weighted distribution of high-beam light sources within each sample. 


\section{Optics trends}

The optics employed in the low-beam headlamps is summarized in Table 4, while the corresponding information for high beams is listed in Table 5. The information in these tables is analogously presented in graphical form in Figures 3 and 4.

The trends for both the low- and high-beam samples show a relatively abrupt transition from mainly lens-based optics in 1997 (67\%) to reflector-based optics in 2007 $(90 \%)$. Additionally, for the first time in these analyses, projector-based optics appear in 2007 as standard equipment on top-selling vehicles within the current sample.

Table 4

Optics of the sampled low-beam headlamps. The entries in each cell are sales-weighted percentages. The most frequently installed equipment for each year is shown in bold.

\begin{tabular}{|l|l|r|r|r|}
\hline \multicolumn{1}{|c|}{ Optics } & 1997 & 2000 & 2004 & 2007 \\
\hline Reflector & 33.4 & $\mathbf{5 1 . 2}$ & $\mathbf{9 3 . 9}$ & $\mathbf{8 9 . 7}$ \\
\hline Lens & $\mathbf{6 6 . 6}$ & 48.8 & 6.1 & 1.5 \\
\hline Projector & & & & 8.8 \\
\hline
\end{tabular}

Table 5

Optics of the sampled high-beam headlamps. The entries in each cell are sales-weighted percentages. The most frequently installed equipment for each year is shown in bold.

\begin{tabular}{|l|l|l|l|r|}
\hline \multicolumn{1}{|c|}{ Optics } & 1997 & 2000 & 2004 & 2007 \\
\hline \hline Reflector & 33.4 & $\mathbf{6 0 . 6}$ & $\mathbf{1 0 0 . 0}$ & $\mathbf{8 9 . 7}$ \\
\hline Lens & $\mathbf{6 6 . 6}$ & 39.4 & & 1.5 \\
\hline Projector & & & & 8.8 \\
\hline
\end{tabular}




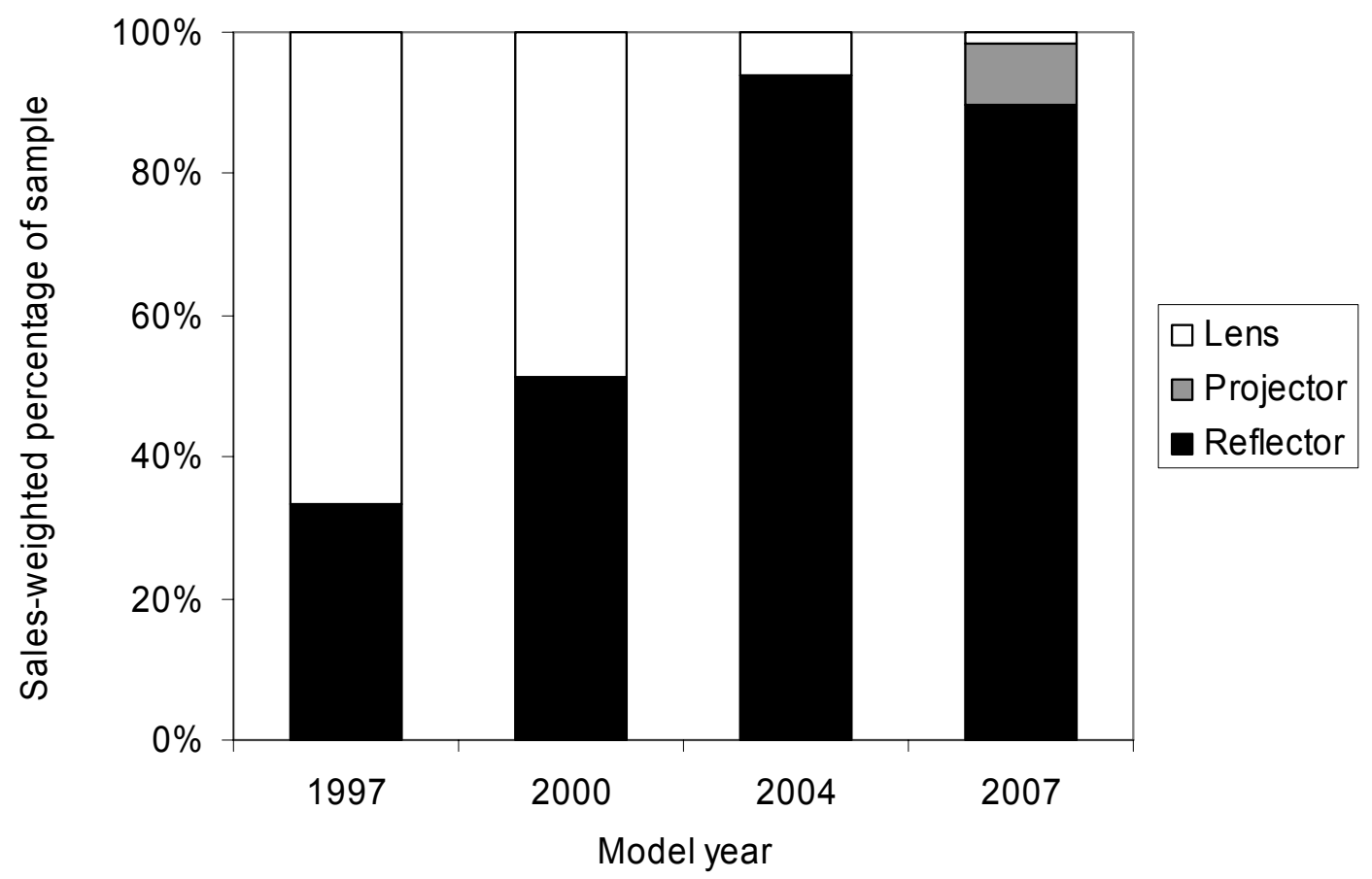

Figure 3. Sales-weighted distribution of low-beam optics within each sample.

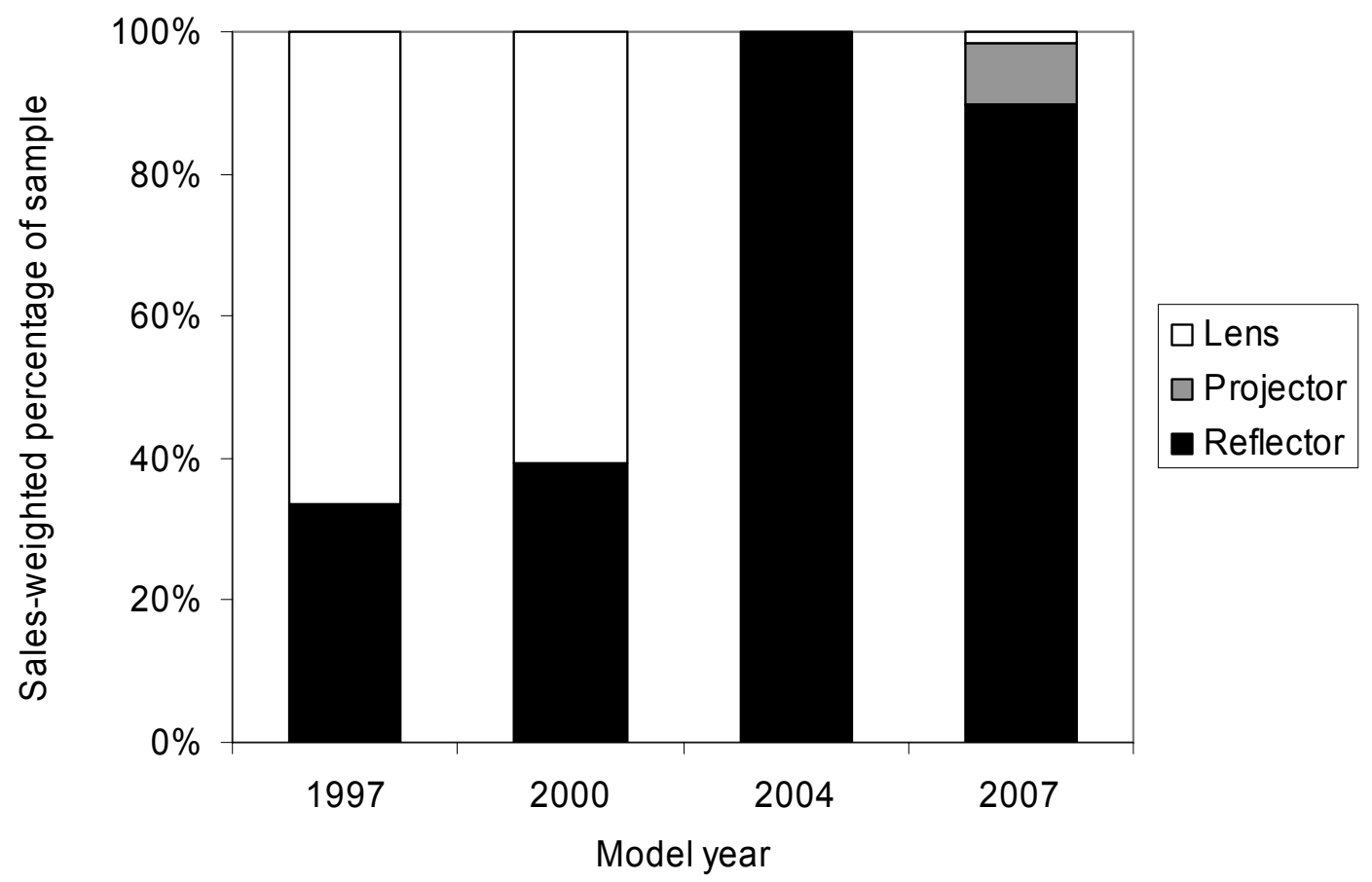

Figure 4. Sales-weighted distribution of high-beam optics within each sample. 


\section{Aiming trends}

The aiming methods specified for the headlamps are summarized in Table 6, and presented graphically in Figure 5.

A clear trend is evident, as headlamp designs transitioned from predominantly mechanical aiming in 1997 (75\%) to nearly exclusive use of visual/optical aiming methods in 2007 (98\%). Within the visual/optical aiming category, visual/optical right side (VOR) aiming leads visual/optical left side (VOL) aiming in prevalence (73\% and $25 \%$ of the most recent sample, respectively). However, the usage of VOL has increased since first appearing in our analyses in 2004 (13\% in 2004, 25\% in 2007). Additionally, VHAD (vehicle headlamp aiming device), which comprised the remainder of the first sample $(25 \%)$ following mechanical aiming, has not been present in the two most recent samples.

Table 6

Specified aiming methods of the sampled lamps. The entries in each cell are salesweighted percentages. The most frequently specified aiming method for each year is shown in bold.

\begin{tabular}{|l|c|c|c|c|}
\hline Aiming method & 1997 & 2000 & 2004 & 2007 \\
\hline \hline Mechanical & $\mathbf{7 4 . 8}$ & $\mathbf{6 1 . 8}$ & 9.4 & 1.5 \\
\hline VHAD & 25.2 & 9.2 & & \\
\hline VOL & & & 13.3 & 25.4 \\
\hline VOR & & 29.0 & $\mathbf{7 7 . 3}$ & $\mathbf{7 3 . 1}$ \\
\hline
\end{tabular}




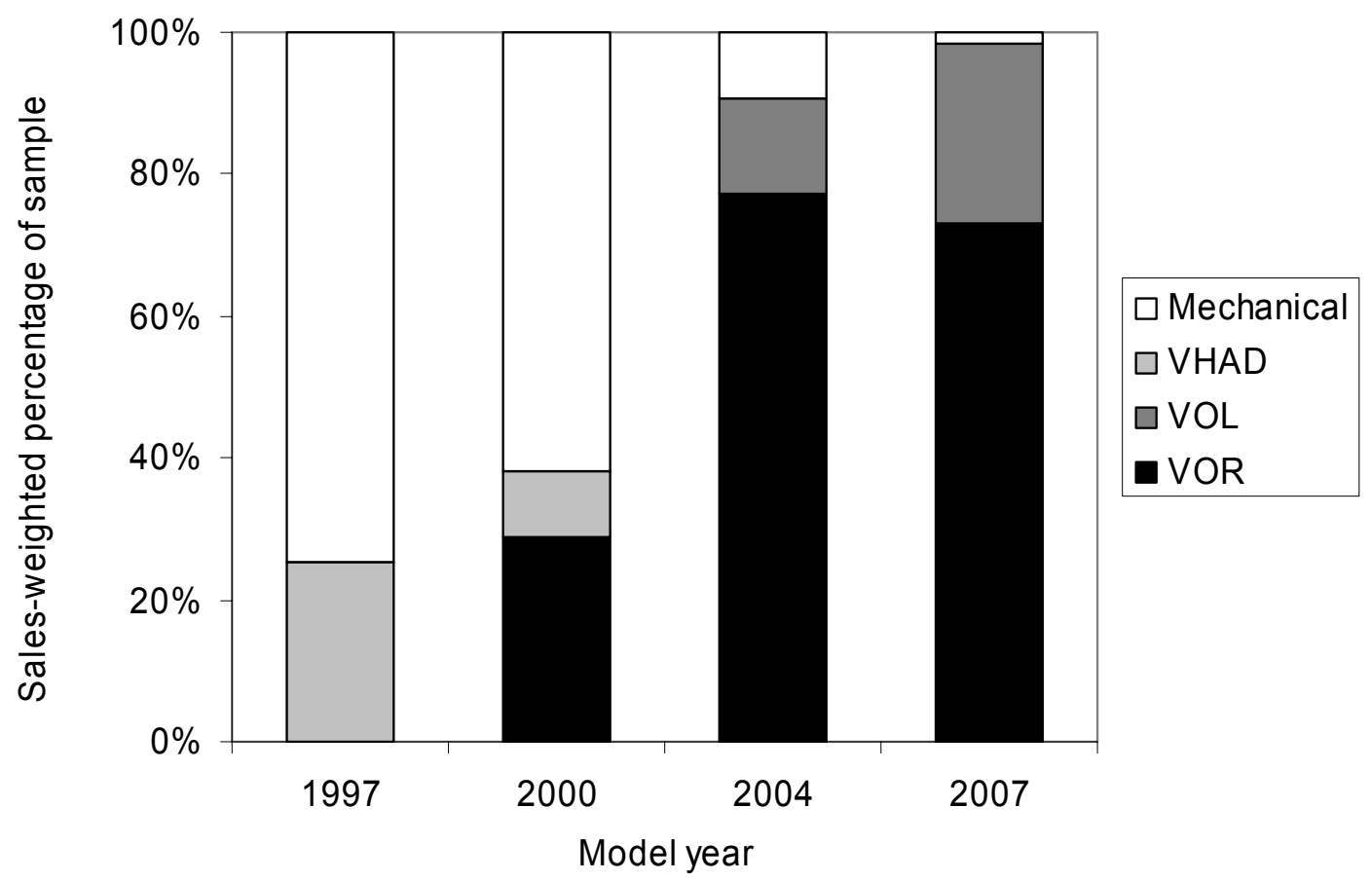

Figure 5. Sales-weighted distribution of the specified aiming methods within each sample.

\section{Lens material trends}

As has been the case since these analyses began in 1997, all U.S. headlamps surveyed for these reports were constructed with plastic outer lenses. 


\section{Conclusions}

This report provided (1) updated information regarding the current marketweighted prevalence of various headlamp design attributes in the U.S. and (2) a summary of recent trends for these design attributes.

There were several main findings. There was a general transition from dualfilament light sources (HB5) in 1997 to single-filament sources (H11 and HB3) in 2007. This trend also indicates a gradual shift from two-lamp systems to four-lamp systems. The preferred optics changed from lens-based (67\%) in 1997 to mostly reflector-based optics $(90 \%)$ in 2007 . The specified aiming methods exhibited the strongest trend. While mechanical aim was typically used in 1997 (75\%), the 2007 sample made nearly exclusive use of visual/optical aiming (98\%), with VOR as the most common specific type (73\%). Table 7 presents summaries of the most common headlamp attributes in the earliest and most recent samples.

Table 7

Summaries of the most common headlamp attributes in the earliest (1997) and most recent (2007) samples.

\begin{tabular}{|l|c|c|}
\hline \multicolumn{1}{|c|}{ Attribute } & 1997 & 2007 \\
\hline \hline Low beam light source & HB5 (9007) & H11 \\
\hline High beam light source & HB5 (9007) & HB3 (9005) \\
\hline Low beam optics & Lens & Reflector \\
\hline High beam optics & Lens & Reflector \\
\hline Aiming method & Mechanical & VOR \\
\hline
\end{tabular}




\section{References}

Automotive News (2001, January 8). Detroit: Crain Communications.

Automotive News (2004, January 12). Detroit: Crain Communications.

Automotive News (2007, January 8). Detroit: Crain Communications.

NHTSA [National Highway Traffic Safety Administration]. (1999a). Submission information on replaceable light source H9 (Document No. 1998-3397-033). Washington, D.C.: U.S. Department of Transportation.

NHTSA [National Highway Traffic Safety Administration]. (1999b). Submission information on replaceable light source H11 (Document No. 1998-3397-034). Washington, D.C.: U.S. Department of Transportation.

NHTSA [National Highway Traffic Safety Administration]. (2002). Information on replaceable light source H13 (Document No. 1998-3397-050). Washington, D.C.: U.S. Department of Transportation.

NHTSA [National Highway Traffic Safety Administration]. (2005). Replaceable Light Source D4R (Document No. 1998-3397-063). Washington, D.C.: U.S. Department of Transportation.

Rumar, K. (2000). Relative merits of the U.S. and ECE high-beam maximum intensities and of two- and four-headlamp systems (Report No. UMTRI-2000-41). Ann Arbor: The University of Michigan Transportation Research Institute.

Schoettle, B., Sivak, M., \& Flannagan, M.J. (2001). High-beam and low-beam headlighting patterns in the U.S. and Europe at the turn of the millennium (Report No. UMTRI-2001-19). Ann Arbor: The University of Michigan Transportation Research Institute.

Schoettle, B., Sivak, M., Flannagan, M.J., \& Kosmatka, W.J. (2004). A market-weighted description of low-beam headlighting patterns in the U.S.: 2004 (Report No. UMTRI-2004-23). Ann Arbor: The University of Michigan Transportation Research Institute. 
Sivak, M., Flannagan, M.J., Kojima, S., \& Traube, E.C. (1997). A market-weighted description of low-beam headlighting patterns in the U.S. (Report No. UMTRI97-37). Ann Arbor: The University of Michigan Transportation Research Institute.

Ward's Automotive Reports (1997, July 14). Southfield, MI: Ward's Communications. 
Appendix A: Vehicles included in the 1997 sample.

\begin{tabular}{|l|l|c|c|}
\hline Model & Maker & Sample share \% & Market share \% \\
\hline \hline F-series & Ford & 10.88 & 4.92 \\
\hline C/K pickup & Chevrolet & 7.78 & 3.52 \\
\hline Explorer & Ford & 5.81 & 2.63 \\
\hline Camry & Toyota & 5.77 & 2.61 \\
\hline Taurus & Ford & 5.62 & 2.54 \\
\hline Ram pickup & Dodge & 5.30 & 2.40 \\
\hline Accord & Honda & 5.13 & 2.32 \\
\hline Civic & Honda & 4.62 & 2.09 \\
\hline Cavalier & Chevrolet & 4.52 & 2.05 \\
\hline Caravan/Grand Caravan & Dodge & 4.38 & 1.98 \\
\hline Ranger & Ford & 4.24 & 1.92 \\
\hline Escort & Ford & 4.08 & 1.84 \\
\hline Grand Cherokee & Jeep & 3.98 & 1.80 \\
\hline SL & Saturn & 3.77 & 1.70 \\
\hline Lumina & Chevrolet & 3.43 & 1.55 \\
\hline Blazer & Chevrolet & 3.36 & 1.52 \\
\hline Corolla & Toyota & 3.25 & 1.47 \\
\hline Grand Am & Pontiac & 3.02 & 1.36 \\
\hline Contour & Ford & 2.33 & 1.05 \\
\hline Grand Prix & Pontiac & 2.25 & 1.02 \\
\hline Intrepid & Dodge & 2.22 & 1.00 \\
\hline Altima & Nissan & 2.16 & 0.98 \\
\hline LeSabre & Buick & 2.10 & 0.95 \\
\hline & & 100.00 & 45.22 \\
\cline { 3 - 4 } & & &
\end{tabular}


Appendix B: Vehicles included in the 2000 sample.

\begin{tabular}{|l|l|c|c|}
\hline Model & Maker & Sample share \% & Market share \% \\
\hline \hline F-series & Ford & 12.86 & 5.05 \\
\hline Silverado & Chevrolet & 9.42 & 3.70 \\
\hline Explorer & Ford & 6.53 & 2.57 \\
\hline Camry & Toyota & 6.21 & 2.44 \\
\hline Accord & Honda & 5.94 & 2.33 \\
\hline Taurus & Ford & 5.61 & 2.20 \\
\hline Ram pickup & Dodge & 5.59 & 2.20 \\
\hline Ranger & Ford & 4.84 & 1.90 \\
\hline Civic & Honda & 4.76 & 1.87 \\
\hline Focus & Ford & 4.20 & 1.65 \\
\hline Caravan/Grand Caravan & Dodge & 4.19 & 1.65 \\
\hline Grand Cherokee & Jeep & 3.99 & 1.57 \\
\hline Cavalier & Chevrolet & 3.48 & 1.36 \\
\hline Corolla & Toyota & 3.38 & 1.33 \\
\hline Blazer & Chevrolet & 3.32 & 1.30 \\
\hline Windstar & Ford & 3.26 & 1.28 \\
\hline Grand Am & Pontiac & 3.15 & 1.24 \\
\hline Expedition & Ford & 3.13 & 1.23 \\
\hline S10 & Chevrolet & 3.10 & 1.22 \\
\hline Malibu & Chevrolet & 3.04 & 1.19 \\
\hline & & 100.00 & 39.28 \\
\hline & & & \\
\hline & & Total: & \\
\hline
\end{tabular}


Appendix C: Vehicles included in the 2004 sample.

\begin{tabular}{|l|l|c|c|}
\hline Model & Maker & Sample share \% & Market share \% \\
\hline \hline F-series & Ford & 13.08 & 5.07 \\
\hline Silverado & Chevrolet & 10.58 & 4.10 \\
\hline Ram pickup & Dodge & 6.95 & 2.69 \\
\hline Camry & Toyota & 6.39 & 2.48 \\
\hline Accord & Honda & 6.15 & 2.39 \\
\hline Explorer & Ford & 5.77 & 2.24 \\
\hline Taurus & Ford & 4.65 & 1.80 \\
\hline Civic & Honda & 4.64 & 1.80 \\
\hline Impala & Chevrolet & 4.14 & 1.61 \\
\hline TrailBlazer & Chevrolet & 4.04 & 1.57 \\
\hline Corolla & Toyota & 3.99 & 1.55 \\
\hline Cavalier & Chevrolet & 3.97 & 1.54 \\
\hline Caravan/Grand Caravan & Dodge & 3.61 & 1.40 \\
\hline Focus & Ford & 3.55 & 1.38 \\
\hline Ranger & Ford & 3.24 & 1.25 \\
\hline Grand Cherokee & Jeep & 3.21 & 1.24 \\
\hline Altima & Nissan & 3.11 & 1.21 \\
\hline Tahoe & Chevrolet & 3.08 & 1.19 \\
\hline Sierra & GMC & 3.04 & 1.18 \\
\hline Expedition & Ford & 2.81 & 1.09 \\
\hline & & 100.00 & 38.78 \\
\hline & & & \\
\hline & & Total: & \\
\hline
\end{tabular}


Appendix D: Vehicles included in the 2007 sample.

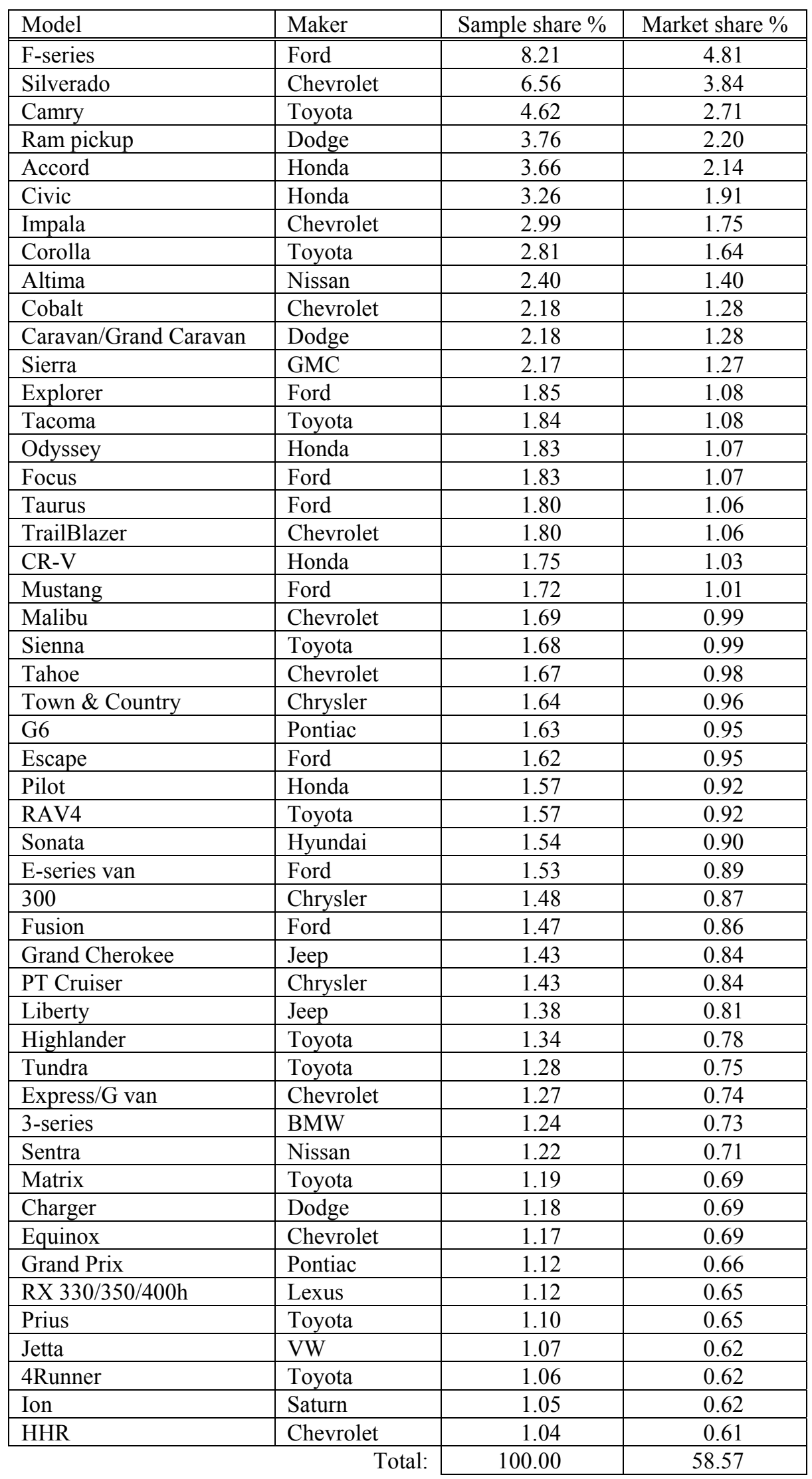

